\title{
Perspectives of wild medicine harvesters from Cape Town, South Africa
}

AUTHORS:

Leif Petersen ${ }^{1,2}$

Andrew M. Reid ${ }^{1}$

Eugene J. Moll ${ }^{3}$

Marc T. Hockings ${ }^{4}$

\section{AFFILIATIONS:}

${ }^{1}$ Sustainable Livelihoods

Foundation, Cape Town,

South Africa

${ }^{2}$ National Research Foundation Centre of Excellence in Food Security; Poverty, Land and Agrarian Studies, University of the Western Cape, Cape Town, South Africa

${ }^{3}$ Biodiversity and Conservation Biology, University of the Western Cape, Cape Town, South Africa

${ }^{4}$ School of Earth and

Environmental Sciences,

University of Queensland

St Lucia, Brisbane, Australia

\section{CORRESPONDENCE TO:}

Leif Petersen

EMAIL:

leif.petersen@livelihoods.org.za

\section{DATES:}

Received: 22 Sep. 2016

Revised: 12 Jan. 2017

Accepted: 22 May 2017

\section{KEYWORDS:}

conservation; wild harvest; sustainability; conflict,

medicinal plants

\section{HOW TO CITE:}

Petersen L, Reid AM, Moll EJ, Hockings MT. Perspectives of wild medicine harvesters from Cape Town, South Africa. S Afr J Sci. 2017;113(9/10), Art. \#2016-0260, 8 pages. http://dx.doi.org/10.17159/ sajs.2017/20160260

\section{ARTICLE INCLUDES: \\ $\checkmark$ Supplementary material \\ $\times$ Data set}

FUNDING:

None

(C) 2017. The Author(s). Published under a Creative Commons Attribution Licence.
Cape Town is a fast-growing cityscape in the Cape Floristic Region in South Africa with 24 formally protected conservation areas including the World Heritage Table Mountain National Park. These sites have been protected and managed as critical sites for local biodiversity, representing potentially one-third of all Cape Floristic Region flora species and $18 \%$ of South Africa's plant diversity. Cape Town is also inhabited by a rapidly growing culturally and economically diverse citizenry with distinct and potentially conflicting perspectives on access to, and management of, local natural resources. In a qualitative study of 58 locally resident traditional healers of distinct cultural groups, we examined motivations underlying the generally illicit activity of harvesting of wild resources from Cape Town protected areas. Resource harvester motivations primarily link to local economic survival, health care and cultural links to particular resources and practices, 'access for all' outlooks, and wholesale profit-seeking perspectives. We describe these motivations, contrast them with the current formal, legal and institutional perspectives for biodiversity protection in the city, and propose managerial interventions that may improve sustainability of ongoing harvest activities.

\section{Significance:}

- The study reveals, for the first time in the Cape Floristic Region, informal economy viewpoints on terrestrial nature and how its direct use has important economic and cultural roles - specifically in wild medicine harvesting and trade.

- We contrast the formal and informal approaches to nature conservation in the city and propose new considerations for conservation managers.

\section{Introduction}

Wild-harvested medicines form part of the historical and contemporary fabric of South African society, and are used by at least 27 million consumers in a largely complementary manner to Western medicine. ${ }^{1}$ The industry represents a 'multimillion rand hidden economy'2 previously estimated to be worth ZAR2.9 billion per year nationally. ${ }^{1}$ The bulk of materials traded as traditional medicines are wild harvested from natural populations in wild habitats, in some cases resulting in adverse ecological impacts through species decline. ${ }^{1,3}$

Since colonial settlement, and now sympatric to this long-established traditional industry, an organised process of legislating and developing policy for conservation and protected area management has been implemented in South Africa, overseen by conservation agencies in a now democratically elected government. These activities have led to the establishment of a legislatively protected and complex array of public and privately managed biodiversity areas, which form the mainstay of modern national and international conservation strategies. ${ }^{4}$ In part due to historical circumstance, ownership or custodianship and the varied management requirements for its diverse landscapes, the formal conservation framework in South Africa reflects a range of concurrent competences, with national and provincial responsibilities, and regionally differing policies with regard to species management. Within this context of formally structured conservation systems, Shackleton ${ }^{5}$ observes that much of the ongoing wild harvest of biological resources from wild habitats takes place in a management vacuum - exacerbated by the lack of a clear government department specifically responsible for sustainable resource use, commonly poor institutional capacity in existing departments, and erosion in traditional authority leadership and communal tenure ${ }^{6}$ which might otherwise play a role in overseeing such activities. The lack of comprehensive oversight of this culturally important harvest has increased conflict between the formal custodians of biodiversity such as protected area managers and many direct users of wildlife resources. This conflict is increasing in Cape Town - the urban centrepiece of the Cape Floristic Region - in which 448 biological species are harvested from public and wild areas in and around the city. ${ }^{7}$ Wild resource harvesting presents new challenges for city conservation officials and is a stated local conservation issue. ${ }^{8}$

Whilst protected area management goals and strategy are clearly articulated and practised in South Africa, less is known about the perspectives of those operating in the informal natural resource trade. Using Cape Town as a study site, we aimed to better understand wild resource harvester motivations for their extraction activities. Conducting research to better understand local harvester livelihood and cultural outlooks towards formal conservation approaches may better inform conservation strategy and natural resource use approaches in the city.

\section{Background}

\section{Protected areas and natural resource harvesting}

Contemporary South African conservation management is administered through a variety of agencies in the three layers of government - national, provincial and local, with around $6 \%$ of South Africa's land surface under some form of legal conservation protection ${ }^{9}$ in nearly 500 state-operated protected areas $^{10}$. South Africa has a further well-developed private nature reserve network based on tourism, game farming and ranching. ${ }^{11} \mathrm{~A}$ comprehensive 
legislative and policy environment linked to the conservation and management of natural resources has been established and implemented (summarised in Appendix 1 of the supplementary material).

There is increasing debate around the role and format of protected area management systems, and the place of people and resource use related to them. ${ }^{12}$ In Africa and South Africa, where poverty is commonplace, these debates are increasingly acute. Despite South African state efforts to protect and manage conservation landscapes, the legalistic and management frameworks put into place have not necessarily led to a decline in local community reliance on natural resources harvesting both within and outside of protected areas. ${ }^{13}$ In some respects, consumptive resource reliance is increasingly pronounced in financially poor rural areas and includes local vulnerability reduction strategies such as collecting fuelwood for heating and cooking, with estimates of reliance on fuelwood as a primary energy source as high as $92 \%$ in Bushbuckridge (a town in the province of Mpumalanga) ${ }^{14}$, and up to $76 \%$ in rural Eastern Cape ${ }^{15}$. Harvesting of wild 'edibles' including marula fruits ${ }^{16}$, mopane worms and bushmeat ${ }^{17}$, is also commonplace. Furthermore, woodcutters and carvers remain largely reliant on wild harvested materials. ${ }^{18}$

A large but almost entirely informal industry is the trade in wild harvested medicine which directly employs at least 133000 people, ${ }^{1}$ including culturally important traditional healers.

\section{Traditional healers}

The varied cultural practice of traditional healing is generally a holistic approach to patient well-being, and considers both spiritual and physical welfare. ${ }^{19}$ Traditional healers vary in practice, and include groups such as predominately black South African inspired amaxwhele who work through a medium of dreams and visions to diagnose patient life-challenges and misfortune, through to Rastafarian-styled bush doctors who provide specialist knowledge services and treatments including those for symptomatic illnesses that could be considered familiar to Western practice. ${ }^{20}$ Predominant in the Western Cape, Eastern Cape and Northern Cape Provinces, many Rasta herbalists claim descendancy links with indigenous Khoi citizens and draw on a diverse pharmacopoeia - including medicines of Cape Dutch, Zulu, Xhosa and European provenance - to treat physical ailments. ${ }^{20}$ The integration of Rasta philosophy and medicinal plant knowledge, embodied in Rasta herbalist practices, emphasises self-sufficiency, attunement with nature and holistic healing. ${ }^{20}$

Related to such practices lie traditional medicine services for treating cultural afflictions. ${ }^{21}$ In this case, illnesses commonly termed Idziso are considered to consume their victims through social misfortune, illness and death. ${ }^{22}$ Removing Idziso (commonly known as 'African poison') requires treatment by powerful professional healer-priests such as amagqirha who use specialised traditional herbal medicines. Such specialists operate at the interface of practising religion, magic and medicine, ${ }^{22}$ maintaining a supernatural contact with ancestral spirits who in turn advise the healer on the causes of patient misfortunes and prescribe the required treatments.

South Africa's widespread traditional healing services support a wild medicine industry that effectively operates in addition to, and sometimes in preference to, Western medical systems. ${ }^{23}$ Traditional healing practices are foundationally different from Western medicine - virtually all healers are trained through oral apprenticeships by elder healers; medicinal ingredients are commonly wild-harvested by healers or traders and transported by foot and informal minibus taxi; and medicines are traded in cash from street or home-based treatment rooms.

\section{Wild medicine industry}

South Africa's wild medicine industry is vibrant, widespread and growing, and utilises an estimated 20000 tonnes of biological materials per year (primarily from the provinces of KwaZulu-Natal, Limpopo, Mpumalanga and the Eastern Cape). South Africa's rich literature includes Mander et al. ${ }^{1,24}$ describing the KwaZulu-Natal and national trades; Botha et al. ${ }^{3}$ examining the Lowveld savannas; Dold and Cocks ${ }^{19}$ investigating the
Eastern Cape harvest and trade; and Williams et al. ${ }^{25}$ exploring the medicinal trade in Gauteng. In response to the growing academic and scientific recognition of these historical linkages between communities and natural resources, there has been a gradual shift in policy and legislative approaches to recognise these activities. This recognition has meant that legislation, policy and institutional efforts have increasingly been framed to allow for potential collaborative opportunities in locallevel natural resources management. Legislation such as the National Environmental Management Act ${ }^{26}$ specifically recognises and articulates the need for

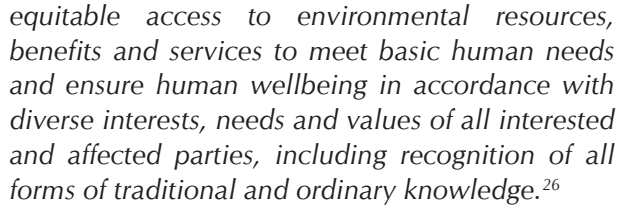

For example, in response to a land claim in the Kruger National Park from the Makuleke community ${ }^{27}$, South African National Parks have attempted a specific local collaborative resource management strategy. Such approaches increasingly dominated the conservation debate around the time of South Africa's transition to democracy ${ }^{12}$ and have subsequently broadened state considerations of public rights and access to resources.

Whilst the legislative and policy environment around the formal protection and management of biodiversity moves away from colonial strategy and increasingly reflects broader community ideals, some authors have highlighted limitations to these approaches. Firstly, as pointed out by Cousins ${ }^{28}$, there is a concern that much legislation and titling in South Africa reflects Western notions of land ownership that are largely unrepresentative of African tenure systems. Secondly, many community-based natural resource management ventures are based on formal property rights which in turn consolidate or marginalise different community groups. ${ }^{29}$ Thirdly, as highlighted by Shackleton ${ }^{5}$, governmental management responsibility for mainstreaming community access to natural resources is largely fragmented and weakly implemented.

Considering the reliance on wild-harvested natural resources for health, well-being and economic purposes in South Africa, and the challenges faced for the nation's broader economic development, there is potential for conflict between biodiversity protection and utilisation perspectives. Certainly, if wild resource harvesting from natural habitats takes place unchecked, the activity could have negative impacts on South Africa's biodiversity, the harvester livelihoods and public health (for those who rely on wild-harvested medicines). By interviewing 58 wild resource harvesters in Cape Town, we aimed to develop an understanding of their perspectives towards natural resources, protected areas and their stated motivations for conducting harvests.

\section{The research site: City of Cape Town}

Cape Town is the capital of the Western Cape Province of South Africa. The well-established historical city occupies land between central Table Mountain National Park and beaches fronting the South Atlantic Ocean. Moving eastwards, the city sprawls onto a large sandy plain of 232 working class 'townships' and informal settlements ${ }^{30}$ locally known as the Cape Flats. The city accommodates 3.84 million people ${ }^{31}$ but is a fast-growing centre, largely as a result of the arrival of up to 13000 predominantly economic migrants per month from the Eastern Cape ${ }^{32}$. Formal unemployment exceeds $60 \%$ in some parts of the city. ${ }^{33}$

Existing research within Cape Town has documented specific aspects of informal trade in local wild-harvested resources. For example, Rebel ${ }^{34}$ noted Proteaceae species being wild-harvested at low levels on the Cape Peninsula; Cowling and Richardson ${ }^{35}$ recorded sour figs (Carpobrotus spp.), honeybush tea (Cyclopia spp.) and buchu (Agathosma spp.) as prominent local foods; Turpie et al. ${ }^{36}$ noted harvesting and informal trade of firewood (introduced Acacia spp.); Clark et al. ${ }^{37}$ highlighted the importance of subsistence fisheries to local economies; and an area of considerable government focus has been local illicit harvesting and export of abalone (Haliotis spp.) linked to criminal syndicates $^{37,38}$. Furthermore, there exists a large but poorly documented 
cash industry of wild medicines operated by diverse cultural groups reliant on wild-harvested biological materials. At least half of all locally harvested species recorded by Petersen et al. ${ }^{7}$ were utilised as wild medicines; Loundou ${ }^{39}$ noted the retailing of 170 medicinal plant species within the city and Nzue ${ }^{40}$ documented the local harvest of 52 species as medicines. Because of conservation legislation and land tenure, many medicinal plant harvests were illegal. As such, this culturally important and prominent informal economy business activity was investigated.

\section{Methods}

Research was undertaken in four Cape Town working-class residential communities in which informal business activity predominates. These communities were selected to be representative of the city's economically marginalised population groups, levels of unemployment, population ethnicity (black and coloured South Africans), urban characteristics (from slum settlements to formalised housing) and geographical spread (Table 1).

Between July and November 2011, we traversed the selected suburbs on bicycle and foot, conducting an informal enterprise census by enumerating natural resource businesses street by street within the suburb boundaries. Some business activities were visually obvious, such as those with signage, whilst others were in unmarked households and identified through participant referrals. From this cohort, traditional healers were invited to participate in a 40-min interview within their business. All healers who readily admitted to harvesting their own wild medicines were interviewed using qualitative open-ended questions on perceptions of formal conservation strategy, individual motivations for wild resource harvesting, challenges for harvesting activities and the business of traditional healing. No prompts were given, in order to limit any researcher bias or influence in answering. To ensure accurate and reflective responses, a culturally representative and multilingual investigatory team was trained by the lead researcher (L.P.) and participated in interviews. Each participant was informed of the objectives of the research and their consent secured. Trust was gained through the extensive mobilisation process whereby the researchers became well known in the local community and word-of-mouth connections were made between traditional healers as to the intentions of the research team.
All responses were anonymised and documented into Microsoft Excel tables for comparative review. As individual interviews were transcribed, responses were grouped into broad themes of harvester perspectives, which were subsequently discussed and confirmed in a focus group of eight traditional medicine practitioners in early 2012.

Ethical clearance for the study was obtained from the University of Queensland.

\section{Results}

A total of 58 wild resource harvesters were interviewed from three predominant traditional healer groupings. None had regular formal sector employment and all highlighted regular (monthly to quarterly) local and regional illicit resource-harvesting activities. All respondents processed and retailed their products through regular or occasional cash sales via personal networks or street vending within local markets (Table 2).

The participants demonstrated a variety of resource access and utilisation viewpoints pertaining to local biodiversity, justifying their harvesting, trading and consumptive activities using a variety of explicit claims and perceived entitlements. Analysis of the field interviews allowed for basic categorisation into a range of utilisation motivations as explicitly claimed by the participants, with many presenting various justifications for their activities (Table 3).

\section{Predominant perspectives}

In the following section, both predominant economic (survivalists and profit seekers) and social themes (cultural requirements, access for all and indigenousness) are similarly grouped together.

Group 1: 'I need this money as I don't have a job' - Economic survival Over $90 \%$ of respondents stated that they conducted wild resource harvesting primarily as an economic survival strategy by generating cash income from sales of wild-harvested resources for livelihood support. Analysis of average household sizes and income streams revealed that natural resource sales were indeed an important livelihood activity for respondents (Table 4).

Table 1: $\quad$ Urban localities in Cape Town sampled for wild harvested natural resource based businesses and traditional healers

\begin{tabular}{|c|c|c|}
\hline Name & Urban characteristic & Population ${ }^{\dagger}$ \\
\hline Capricorn & Formalised, electrified urban settlement comprising patron-funded three-room brick houses & 18270 \\
\hline Overcome Heights & Largely unserviced informal settlement of owner-built shack dwellings & 11587 \\
\hline Seawinds & Formalised, electrified urban settlement comprising privately built and patron-funded brick houses & 7689 \\
\hline Sweet Home & Largely unserviced informal settlement of owner-built shack dwellings & 16000 \\
\hline Total population sample & & 74977 \\
\hline
\end{tabular}

${ }^{\dagger}$ Population data derived from Statistics South Africa ${ }^{41}$ updated by Census Plus ${ }^{42}$ and high-resolution aerial photo dwelling counts.

Table 2: $\quad$ Typologies of traditional healers interviewed to determine motivations for wild harvesting and trading in natural resources

\begin{tabular}{l|l|l|l}
\hline \hline \multicolumn{1}{c|}{ User } & \multicolumn{1}{|c|}{ Method of trade } & \multicolumn{1}{c}{ Number } \\
interviewed
\end{tabular}


Table 3: Explicit natural resource utilisation claims of traditional healer research participants

\begin{tabular}{|c|c|c|c|}
\hline $\begin{array}{l}\text { Utilisation } \\
\text { perspective }\end{array}$ & Description & $\begin{array}{l}\text { Explicit } \\
\text { claim }\end{array}$ & $\begin{array}{l}\text { Percentage of } \\
\text { respondents }\end{array}$ \\
\hline Economic survival & Harvesting to bolster household resource and income security & 53 & $92 \%$ \\
\hline Cultural requirements & Harvesting to fulfil well-established and continuing demands linked to family or community history & 52 & $89 \%$ \\
\hline Access for all & A perspective of generalised open-access rights to landscapes to collect resources & 46 & $80 \%$ \\
\hline Indigenousness & $\begin{array}{l}\text { Individuals claiming a historical continuity with pre-colonial societies that developed on their territories; } \\
\text { consider themselves distinct from the state }\end{array}$ & 13 & $22 \%$ \\
\hline Profit seeking & $\begin{array}{l}\text { Harvesters who seek to generate increasing personal wealth from natural resource products through illicit } \\
\text { harvesting and informal trading opportunities }\end{array}$ & 5 & $8 \%$ \\
\hline
\end{tabular}

Table 4: Economic contribution of wild harvested resources to traditional healer households

\begin{tabular}{|c|c|c|c|c|}
\hline User type & Average household size & $\begin{array}{l}\text { Total household income per month, } \\
\text { in ZAR (USD) }\end{array}$ & $\begin{array}{l}\text { Resource-based income per } \\
\text { month, in ZAR (USD) }\end{array}$ & $\begin{array}{l}\text { Percentage contribution of } \\
\text { wild resources }\end{array}$ \\
\hline Amagqirha & 4.8 & 2916 (243) & 2364 (197) & $81 \%$ \\
\hline Rastafarian herbalists & 3.1 & $6708(559)$ & $4008(334)$ & $59 \%$ \\
\hline Amaxwhele & 3.0 & $2820(235)$ & $1380(115)$ & $49 \%$ \\
\hline
\end{tabular}

An average exchange rate for 2012 of USD1 = ZAR12.00 was used.

In all cases, despite the potential illegality of the activity, half or more of household income was based on wild-harvested resources. For the amagqirha in particular, the economic reliance on wild resources was considerable, especially in light of the large average household size.

Many respondents claimed to harvest and trade wild-harvested resources because of a lack of alternative income-earning opportunities, retrenchment, and the need for cash income. Few were exclusively reliant on this income stream - more than half $(55 \%)$ of the respondents came from households which received social grants from government (either old-age pensions or child-support grants), whilst $43 \%$ lived in households with income from non-natural resource related work. Considering the high relative contribution of natural resource incomes in all households, it is evident that the wild harvest of natural resources enhances economic survival for these residents, certainly propelling many above minimum living levels of ZAR744 (USD62) per person per month. ${ }^{43}$ Additionally for some Rastafarian healers, there was considerable personal consumption of harvested wild resources as medicine - effectively subsidising their household health care and allowing them to save financial resources from other economic activities. For those living on the fringes of the cash economy, the reliance on wild-harvested resources was substantial in terms of both income opportunities and personal consumption, and these products served as an important safety net. ${ }^{44,45}$

Group 2: 'I'm in business to make money' - Profit seeking

Building on economic survivalist motives, the relatively rapid emergence of South Africa's modern economy in the last few hundred years, coupled with cash demand for culturally important items, has created large commercial markets for wild-harvested resources. ${ }^{1}$ In this case, capitalistic entrepreneurs - commonly utilising traditional knowledge seek to derive increasing commercial benefit from wild harvesting of natural resources. Although similar to motives of economic survival, two entrepreneurial respondents were utilising motor vehicles, plant shredders and other dedicated machinery to harvest and process wild resources, and were selling on bulk quantities of processed resources to other healers. Like local extraction of Haliotis midae ${ }^{38}$, these activities were increasingly clandestine and organised compared to the activities of other harvesters. Potential profiteering activities identified by this research include the extraction of the indigenous medicinal plant Tulbaghia capensis (wild garlic) of which 16000 bulbs were confiscated from up to 50 known (and repeatedly arrested) individuals illicitly harvesting in the city-managed 300 -ha Tygerberg Nature Reserve over 2 years from 2010 (Glanville P 2011, personal communication, November). Law enforcement records in the reserve show that some arrests linked to this activity realised hundreds of bulbs confiscated from individual collectors at any one time - greatly exceeding quantities for personal or cultural use typified by the resource stockpiles of the majority of respondents, with produce reportedly heading to local informal trading markets throughout and beyond the city.

Group 3: 'We need the herbs to heal the people' - Health and wellbeing

For many South Africans, plant medicines are sought as stabilisers and proactive responses to the precarities and uncertainties of everyday life: the need to secure employment, attract a potential partner, or realign one's conduct in relation to past generations of family. ${ }^{46,47}$ These volatilities are often heightened in densely populated urban areas where people may be exposed to physical and psychological trauma or ill-health as a result of disease (TB/HIV being examples), substance abuse, or diets founded on nutrient-poor foods high in sugar and fat. In addition, aspirations to success and heightened prestige in highly competitive urban contexts are threatened by the limited availability of, and access to, necessary resources and opportunity. Contemporary urban citizens with familial histories of medicinal plant use continue to draw on these practices holistically to help promote their well-being and greater future prosperity, by cleansing themselves, family members and their immediate surroundings. ${ }^{21,48,49}$ Traditional healers serve as a vital source of medicinal plants and knowledge for health and wellbeing. Nearly $90 \%$ of respondents highlighted the cultural importance of conducting the wild harvesting of medicinal resources themselves. This cultural influence remains deeply rooted, with the amagqirha in particular describing themselves as 'their ancestors' servants', suggesting that a set of higher forces controlled their day-to-day traditional practices, necessitating wild resource harvest practices and use.

In addition to their use as well-being enhancing medicines, plants are commonly sought out and relied on to treat physical ailments such as diarrhoea, arthritis and high blood pressure. ${ }^{1,47}$ Importantly, the introduction and rise of commercial pharmaceuticals in South Africa 
has not radically altered traditional healer beliefs, rather these newer technologies and tools are commonly used in a complementary, alternative and integrative manner with traditional medicine. ${ }^{48}$ Similar trends involving the fluid integration of multiple treatment approaches are seen around the world. ${ }^{50-52}$ One traditional healer respondent illustrated this point stating that 'the clinic is for Western problems' with another stating that 'there are no tablets for a job at the clinic'. The health and well-being requirement fosters continued consumer demand for locally occurring wild resources and remains an important driver for local resource harvesters of all backgrounds.

Group 4: 'These herbs belong to the people' - Access for all viewpoints As much as $80 \%$ of respondents highlighted their perceived rights to access local protected areas and natural resources for the purposes of consumptive harvesting. The basis of this viewpoint is a perspective of open access rights to resources, with wild habitats considered as important sources for biological materials. Many of Cape Town's black African citizens (including 44 of the 45 black South African amagqirha and amaxwhele in this research) were born in apartheid-established Bantustans in the current-day Eastern Cape Province. Historically, these territories were managed under state sanctioned regimes of local traditional leadership, and in a complex mix of tenure systems including trusts, quitrent, freehold, communal and tenancy arrangements, with little freehold land ${ }^{53}$ Before and after South Africa's democratic transition, these localities have remained largely under local community control, with many openly used as sources for wild medicinal plants under systems of community control. For many recent Cape Town migrants from these localities, utilisation outlooks towards land and natural resources are common, with local state property and protected areas reportedly being seen as new harvest sites for collections. However, in this case, fencing, conservation management and law enforcement have become the 'occupational hazards' 5 in a landscape under a different form of (state) control.

Group 5: 'We are the original people and this land is for all of us' Indigenousness

The United Nations ${ }^{54}$ generally considers indigenous peoples to be those who, having a historical continuity with pre-colonial societies that developed on their territories, consider themselves distinct from other sectors of the societies now prevailing on those territories. Within Cape Town, claims of indigenousness primarily emanate from those claiming descendancy from the Khoi peoples present at the time of European settlement but largely eliminated from the City as a result of various colonial practices and cultural suppression..$^{55}$

The seven interviewed Rastafarians of coloured ethnicity highlighted immediate local indigenousness and concurrent herbal knowledge as an important political justification for their activities. Rastafari herbalists participating in the study were keenly aware of the historical legacy of colonial oppression and claims of indigenousness were expressed and justified through proclaimed and evidenced knowledge of Khoi culture, heritage and cultural ascription. ${ }^{56}$ For those making indigenous claims, mainstream societal laws, land ownership and modern conservation protection methods were considered non-applicable and politically unjustifiable. The emotional significance of these perceived entitlements with respect to wild gathering plants from the local Table Mountain National Park was embodied in a statement by one Rastafarian participant: 'I need these herbs for my heart to be secured'. Another participant framed access to medicinal plants in terms of post-apartheid reparation: 'These herbs are our inheritance. District Six was returned to the people who were moved from there and these herbs must be returned to us.'

\section{Discussion}

\section{Formal protected areas and informal use}

South Africa's formal system of protected areas primarily serves the broader interests of society and the economy through the protection of biodiversity, scenery and watersheds, and the promotion of tourism and other attributes. ${ }^{9}$ Despite legal protection, Cape Town conservation landscapes are under increasing threat from high rates of local population growth and urbanisation, alien plant invasion and climate change. ${ }^{57}$ Adding pressure is a growing local informal economy based on wildharvested natural resources. ${ }^{7}$ Individuals conducting these harvests demonstrated cultural and livelihood motivations that differ from the perspectives and motivations of the formal framework of conservation planning and management, expressed largely through cultural and economically driven consumptive use. An overarching difference underpinning various harvester motivations relates to perceived 'usage rights' over resources growing on state and private land, which for many in the study are viewed as belonging to supreme deities. ${ }^{58}$

Importantly, despite individual harvest impacts (which in some cases were considerable) all research participants demonstrated considerable appreciation of the broader merits of biodiversity conservation. However, additional to this appreciation was a range of perceived user rights to resources underpinned by various economic, cultural and historical experiences and expressed in the widespread wild harvest and trade of hundreds of species of flora and fauna from within the City. ${ }^{7}$ These largely informal 'livelihoods or culturally driven' activities potentially conflict with dominating 'protection driven' conservation strategy. Figure 1 presents a theoretical framework representing how participants in Cape Town's informal traditional medicine economy, underpinned by various economic and anthropogenic drivers, interpret local nature in contrast with formal approaches.

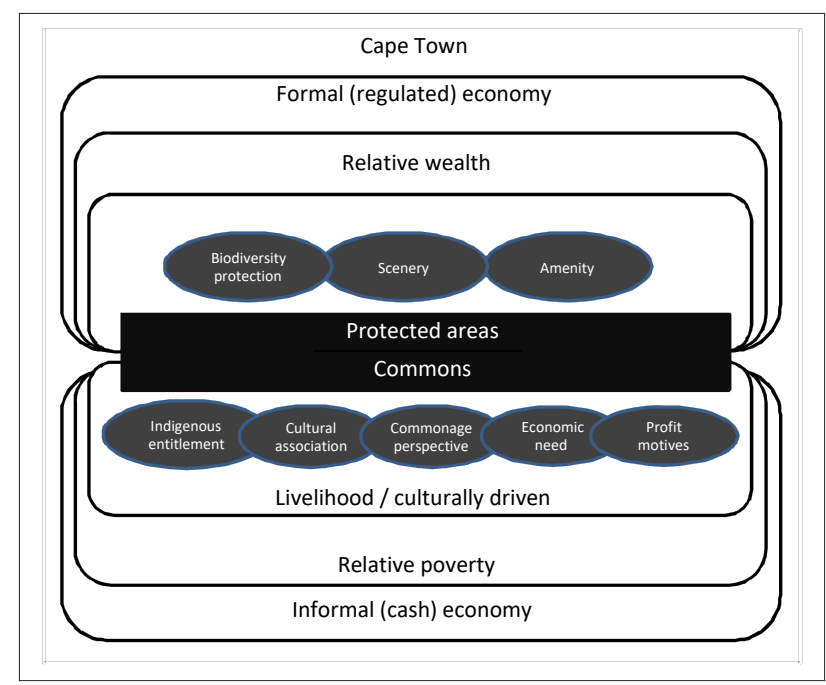

Figure 1: Theoretical framework highlighting anthropogenic perspective differences for Cape Town nature.

Originating in the informal economy under conditions of poverty, the harvesters of wild resources conduct this activity to satisfy health and well-being demands in local cash markets. The medicinal plant harvest and trade makes an important contribution to economic livelihoods, without which $76 \%$ of research participants would be living in conditions of financial poverty. Many interviewed in this research considered the formal, legalistic and protection driven outlook towards nature conservation as a middle-class interpretation of how nature should be maintained, which was considered culturally insensitive and ignorant of their lived reality of social and economic marginalisation.

Under present conditions, the intersection of formal conservation practice with natural resource extraction for the growing informal economy will inevitably lead to conflict. The formal local conservation approach to ecological systems through legislated protected areas, 'fines and fences', and primarily non-consumptive use is challenged by the views and activities of traditional healer participants in this research.

Evolving health-care practices and natural resource demand The highly entrenched and growing demands for wild harvested medicines in South Africa ${ }^{1-3}$ and the largely complementary role to Western medicine ${ }^{1}$ means consumer preferences for this service and 
related products are unlikely to decline in the near future. Further, the perspectives of various groups of natural resource harvesters and traders require acknowledgement by state conservation and natural resource agencies. In adapting to such use, programmes of community-based natural resource management have been implemented under broader ecological and economic sustainability objectives such as those outlined in the Secretariat of the Convention on Biological Diversity. ${ }^{59}$ However, post-colonial indigenous-linked cultures and practices combined with the growing influence of cash, trade and technology makes for a very different relationship between 'traditional' people and nature when compared with historical situations in less densely populated contexts. Contemporary relationships involving indigenously rooted practices, practitioners and natural resources bring perceptions of ecologically friendly local communities, as commonly portrayed in popular media, into question. ${ }^{60}$ As highlighted by Cocks ${ }^{61}$, in many respects, the worldviews, cultural values and knowledge of large sectors of the population in [South] Africa can no longer be classified as 'traditional' nor as representative of Western culture. Rather, the shifting arrangements of life in contemporary South Africa - resulting in part from accelerated urban migration, unemployment and disease - stimulate dynamic and adaptive responses from individuals in order to secure livelihoods, in this case, through the harvest and trade of natural resources.

It was apparent in the local setting that traditional healer outlooks towards biodiversity appear largely economically and culturally entwined. This blending of motivations makes for complex and subjective arguments both for and against local consumptive wild resource utilisation. Figure 2 demonstrates how the influence of the cash economy has stimulated an evolution of wild resource harvesting and trade from more 'traditional' drivers within the context of cultural, subsistence or indigenous claims towards a spectrum of increasingly informal livelihood and incomedriven informal and entrepreneurial motivations. The influence of cash motives into these harvest activities can evolve this 'traditional' harvesting into an 'informal' economy activity driven by cash and profit, and which include increasingly entrepreneurial collectors.

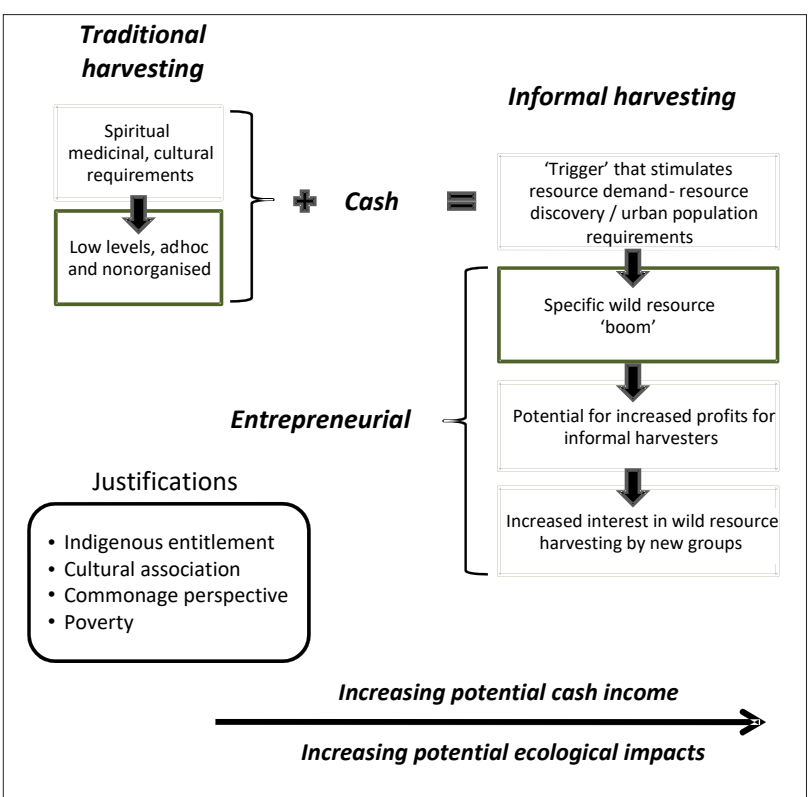

Figure 2: The evolution of illicit natural resource harvesting motivations in Cape Town residents.

In Cape Town, the drivers of natural resource harvesting for informal economy trade are evolving as the influence of cash markets in the sector grows. Coupled with this increase are greater potential impacts on conservation and protected area management. Thus, despite Cape Town's well-established, formalised, legally enforceable and ecologically critical protected area network, in light of anthropogenic drivers of poverty and cultural demands there remains a strong likelihood that wild resource harvesting from these areas will continue and may grow.

\section{The conservation challenge}

The variety of resource utilisation perspectives demonstrated by traditional healers, and evolving drivers of harvest, present a growing challenge for state attempts to balance biodiversity protection with local economic development needs. That said, the local situation reflected in this research is not necessarily unique - it reflects the deep political and social complexity inherent in conservation work in developing countries. ${ }^{60}$

In the absence of any one specific South African government agency specifically mandated to deal with natural resource use (as raised by Shackleton ${ }^{5}$ ) there is a need for relevant conservation agencies to consider the drivers and impacts of this activity. Within Cape Town, this consideration includes engagement with these issues by local authorities (Cape Town Nature Conservation), provincial (CapeNature) and national (South African National Parks) bodies - all of which directly manage biodiversity resources in and around the city. Practically, from their formal protected area management perspective, more assessments of local ecology are needed at smaller (reserve or species) scales ${ }^{62}$ to better understand and monitor harvest impacts and to inform management responses to harvest risks. Where biodiversity risks are pronounced from wild resource collections, stricter protected area boundary maintenance coupled with basic social relief services as suggested by Wilshusen et al. ${ }^{60}$ could be considered - such as raising local awareness of existing social protection grants and measures. In circumstances of genuine and provable local cultural ties to resources, the negotiation of legitimate and binding agreements for controlled harvesting could be undertaken on legally appropriate landholdings - although the number and diversity of traditional healer types and resource claimants will be highly problematic to manage or enforce with limited state resources.

Beyond conservation managers there is a need for municipal parks, gardens and public space managers to engage in practical land management activities such as encouraging publicly accessible harvest projects and landscapes within the urban landscape. As seen with the rise in cash trade, patterns of reliance on, and trade in, wild harvested medicines are not impervious to adaptation and change (see also Botha et al. ${ }^{3}$, Dold and Cocks ${ }^{63}$ ). Whilst wild harvesting remains the current healer preference, it is possible that alternative strategies for resource collection, such as cultivation schemes, may gain local support. Although traditional healer groups are ethnically diverse and varyingly motivated, conservation agency supported planting of culturally important species could take place where suitable landholdings can be identified. Allowing harvests of these biological materials under an 'open-access' regime (as per current largely illicit collections) may allow divergent harvester groups the opportunity to continue their trade without necessarily compromising the biological integrity of local protected areas.

\section{Conclusions}

Contemporary protected areas in Cape Town conserve important biodiversity for South Africa. However, beyond the conventional scientific rationale for their protection, they are also seen from perspectives of diverse origins, with some considering consumptive use such as wild resource harvesting from these areas as an economic and cultural necessity. These different ways of understanding and appreciating nature underpin an emerging resource use conflict within the City. The geographical constraints of Cape Town combined with the increasing fragility of local biodiversity and emerging cash drivers of wild resource harvesting mean that, from a biodiversity protection perspective, unconstrained consumptive usage of wild resources is ecologically problematic. Importantly, enhancing understanding of harvester and alternative views of conservation beyond this study could assist in devising more inclusive and reflective conservation management practices - even for non-conservation lands that could be utilised for biodiversity business. Through such activities, the development of alternative livelihood opportunities around the culturally and economically important harvest of natural resources is required in ways that will not compromise ecological and industry sustainability in a dynamic and changing Cape Town society. 


\section{Acknowledgements}

We thank Andrew Charman, Ray Collins and colleagues at the Sustainable Livelihoods Foundation.

\section{Authors' contributions}

L.P. was responsible for the literature review, methodology, field work, analysis and write-up; A.M.R. was responsible for field work and analysis; E.J.M. was responsible for the literature review, methodology and revision; M.T.J. was responsible for the literature review and supervision.

\section{References}

1. Mander M, Ntuli L, Diedrichs N, Mavundla K. Economics of the traditional medicine trade in South Africa. FutureWorks Report for Ezemvelo KZN Wildlife; 2007. Unpublished report.

2. Cunningham $A B$. Herbal medicine trade: A hidden economy. Indicator $S$ Afr. 1989;6:51-54.

3. Botha J, Witkowski ETF, Shackleton C. Market profiles of medicinal plants in the Lowveld, South Africa. Environ Conserv. 2004;31:38-46. https://doi. org/10.1017/S0376892904001067

4. Hannah L, Midgley G, Andelman S, Araújo M, Hughes G, Martinez-MeyerE, etal. Protected area needs in a changing climate. FrontEcol Environ. 2007;5(3):131138. https://doi.org/10.1890/1540-9295(2007)5[131:PANIAC]2.0.C0;2

5. Shackleton $\mathrm{C}$. Will the real custodian of natural resource management please stand up. S Afr J Sci. 2009;105(3-4):91-93.

6. Cousins B, Hall R. The potential and limits of rights-based approaches to securing land tenure in rural South Africa. In: Langford M, Dugard J, Madlingosi T, Cousins B, editors. Symbols or substance? The role and impact of socio-economic rights strategies for Africa. Cambridge: Cambridge University Press; 2015.

7. Petersen LM, Moll EJ, Collins RJ, Hockings MT. Development of a compendium of local, wild-harvested species used in the informal economy trade, Cape Town, South Africa. Ecol Soc. 2012;17(2):26. http://dx.doi.org/10.5751/ES04537-170226.

8. Holmes PM, Rebelo AG, Dorse C, Wood J. Can Cape Town's unique biodiversity be saved? Balancing conservation imperatives and development needs. Ecol Soc. 2012;17(2):28. http://dx.doi.org/10.5751/ES-04552-170228

9. South African National Biodiversity Institute (SANBI). Biodiversity Geographic Information System. Pretoria: SANBI; 2010.

10. South African Department of Environmental Affairs and Tourism (DEAT). Convention on Biological Diversity thematic report on protected areas or areas where special measures need to be taken to conserve biological diversity. Pretoria: DEAT; 2003.

11. Carruthers J. Wilding the farm or farming the wild? The evolution of scientific game ranching in South Africa from the 1960s to the present. Trans R Soc South Afr. 2008;63(2):160-181.

12. Adams WM, Hutton J. People, parks and poverty: Political ecology and biodiversity conservation. Conserv Soc. 2007;5(2):147-183.

13. Sunderland T, Ndoye 0 , editors. Forest products, livelihoods and conservation. Bogor-Barat: Centre for International Forest Management; 2004.

14. Madubansi M, Shackleton C. Changing energy profiles and consumption patterns following electrification in five rural villages, South Africa. Energy Pol. 2006;34(18):4081-4092. https://doi.org/10.1016/j.enpol.2005.10.011

15. Shackleton CC, Gambiza J, Jones R. Household fuelwood use in small electrified towns of the Makana District, Eastern Cape, South Africa. J Energy South Afr. 2007:18:3.

16. Shackleton $\mathrm{S}$. The informal marula beer traders of Bushbuckridge, Limpopo Province, South Africa. DFID/FRP Winners and Losers in Forest Product Commercialisation, Project No. ZF0140/R7795. Grahamstown: Rhodes University; 2002

17. Cook B. A bloody trade. London: World Wide Fund for Nature; 2004

18. Shackleton C, Shackleton S. The Pterocarpus angolensis DC. based woodcraft industry in the Bushbuckridge district, South Africa. In: Sunderland T, Ndoye 0, editors. Forest products, livelihoods and conservation. BogorBarat: Centre for International Forest Management; 2004.
19. Dold AP, Cocks ML. The trade in medicinal plants in the Eastern Cape Province, South Africa. S Afr J Sci. 2002;98(11-12):589-597.

20. Aston Philander L. An ethnobotany of Western Cape Rastafarian bush medicine. J Ethnopharmacol. 2011;138(2):578-594.

21. Cocks ML, Dold AP. The role of 'African Chemists' in the health care system of the Eastern Cape province of South Africa. Soc Sci Med. 2000;51:15051515. https://doi.org/10.1016/S0277-9536(00)00050-2

22. Ashforth A. Reflections on spiritual insecurity in a modern African city (Soweto). Afr Stud Rev. 1998;41(3):39-67. https://doi.org/10.2307/525353

23. Natrass $N$. Who consults sangomas in Khayelitsha? An exploratory quantitative analysis. Working paper. Cape Town: Centre for Social Science Research, University of Cape Town; 1998.

24. Mander M. Marketing of indigenous medicinal plants in South Africa. Rome: Food and Agriculture Organization of the United Nations; 1998.

25. Williams V, Witkowski E, Balkwill K. Volume and financial value of species traded in the medicinal plant markets of Gauteng, South Africa. Int J Sustain Dev World Ecol. 2007;14:584-603. https://doi.org/10.1080/13504500709469757

26. National Environmental Management Act, No 107 of 1998, Government of the Republic of South Africa.

27. Maluleke ML. The Makuleke story [document on the Internet]. No date [cited 2016 Sep 15]. Available from: http://www.earthlore.ca/clients/WPC/English/ grfx/sessions/PDFs/session_1/Maluleke.pdf

28. Cousins B. Legislating negotiability: Tenure reform in post-apartheid South Africa. In Juul K, Lund C, editors. Negotiating property in Africa. Portsmouth, NH: Heineman; 2002. p. 67-106.

29. Neimark B. Subverting regulatory protection of 'natural commodities': The Prunus africana in Madagascar. Dev Change. 2010;41(5):929-954. https:// doi.org/10.1111/j.1467-7660.2010.01666.x

30. General statistical data for City of Cape Town. Cape Town: City of Cape Town Strategic Information and GIS Department; 2007. Unpublished internal report.

31. Statistics South Africa. National census 2011 [document on the Internet] c2012 [cited 2017 Jan 12]. Available from: https://www.statssa.gov.za/ publications/P03014/P030142011.pdf

32. Poswa N, Levy R. Migration study in Monwabisi Park, Khayelitsha - City of Cape Town. Cape Town: Strategic Development Information and GIS Department, Strategic Information Branch; 2006

33. South African Department of Social Development (DSD). Khayelitsha Livelihood profile of Khayelitsha and situational analysis of DSD services in the node. Pretoria: DSD; 2007.

34. Rebelo AG. The utilisation of proteas. An unsolicited report for SAPPEX in recognition of its contribution to the Protea Atlas Project. 1996.

35. Cowling RM, Richardson DM. Fynbos: South Africa's unique floral kingdom. Cape Town: Fernwood Press; 1995.

36. Turpie JK, Heydenrych BJ, Lamberth SJ. Economic value of terrestrial and marine biodiversity in the Cape Floristic Region: Implications for defining effective and socially optimal conservation strategies. Biol Conserv. 2003;112:233-251. https://doi.org/10.1016/S0006-3207(02)00398-1

37. Clark BM, Hauck M, Harris JM, Salo K, Russell E. Identification of subsistence fishers, fishing areas, resource use and activities along the South African coast. Afr J Mar Sci. 2002;24:425-437. https://doi. org/10.2989/025776102784528574

38. Steinberg J. The illicit abalone trade in South Africa. Pretoria: Institute for Security Studies; 2005

39. Loundou P. Medicinal plant trade and opportunities for sustainable management in South Africa [master's thesis]. Stellenbosch: Stellenbosch University; 2008

40. Nzue APM. Use and conservation status of medicinal plants in the Cape Peninsula, Western Cape Province of South Africa [master's thesis]. Stellenbosch: Stellenbosch University; 2009.

41. Statistics South Africa. Population census South Africa: 2001 [document on the Internet]. c2001 [cited 2017 Jan 12]. Available from: http://www.statssa. gov.za/?page_id=3892 
42. Census Plus. Enhanced datasets based on Statistics South Africa Census 2001 [database on the Internet]. c2007 [cited 2017 Jan 12].

43. Finn A, Leibbrandt M, Levinsohn J. Income mobility in South Africa: Evidence from the First Two Waves of the National Income Dynamics Study. SALDRU Working Paper Number 82 / NIDS Discussion Paper 2012/5. Cape Town: SALDRU, University of Cape Town; 2012.

44. Shackleton C. Assessment of the livelihoods importance of forestry, forests and forest products in South Africa. Grahamstown: Rhodes University; 2004. Available from: http://www2.dwaf.gov.za/dwaf/cmsdocs/Elsa/Docs/Forests/ Assessment\%20 of\%20the \%20Livelihoods\%20Importance $\% 20$ of $\% 20$ Forestry,\%20Forests\%20and\%20Forest $\% 2$ Products $\% 20 \mathrm{in} \% 20$ SA, $\% 20$ 2004.pdf

45. Shackleton $\mathrm{C}$, Shackleton S. The importance of non-timber forest products in rural livelihood security and as safety nets: A review of evidence from South Africa. S Afr J Sci. 2004;100(11-12):658-664.

46. Hutchings $A$, Scott $A$, Lewis G, Cunningham AB. Zulu medicinal plants: An inventory. Pietermaritzburg: University of Natal Press; 1996.

47. Van Wyk BE, Gericke N. People's plants: A guide to useful plants of southern Africa.. Pretoria: Briza; 2000.

48. Cocks ML, Møller V. Use of indigenous and indigenised medicines to enhance personal well-being: A South African case study. Soc Sci Med. 2002;54:387397. https://doi.org/10.1016/S0277-9536(01)00037-5

49. Ngubane $\mathrm{H}$. Body and mind in Zulu medicine: An ethnography of health and disease in Nyuswa-Zulu thought and practice. London: Academic Press; 1977.

50. Chan K. Chinese medicinal materials and their interface with Western medical concepts. J Ethnopharmacol. 2005;96(1):1-18.

51. Hunt LM, Arar NH, Lakana LL. Herbs, prayer, and insulin. Use of medical and alternative treatments by a group of Mexican American diabetes patients. J Fam Pract. 2000;49(3):216-223.

52. Shahid S, Bleam R, Bessarab D, Thompson SC. 'If you don't believe it, it won't help you': Use of bush medicine in treating cancer among Aboriginal people in Western Australia. J Ethnobiol Ethnomed. 2010;6:18. https://doi. org/10.1186/1746-4269-6-18

53. Weideman M. Tenure reform: The former homelands [document on the Internet]. c2004 [cited 2016 Jul 12]. Available from: http://wiredspace.wits. ac.za/bitstream/handle/10539/275/20_chapter8.pdf?sequence $=20$
54. United Nations. Workshop on data collection and disaggregation for indigenous peoples; 2004 January 19-21; New York, USA. Available from: http://www.google.co.za/url?sa =t\&rct=j\&q=jose\%20r.\%20martinez $\% 20$ cobo\&source $=$ web\&cd $=1 \&$ ved $=0$ CFQQFjAA\&url $=h t t p \% 3 A \% 2 F \% 2 F w w w$. un.org\%2Fesa\%2Fsocdev\%2Funpfii\%2Fdocuments\%2Fworkshop_data background.doc\&ei $=$ Fcn-T7TiKoyGhQf-6bngDQ\&usg =AFQjCNFMb2Ln4Aq UEFKk_8ozGuEM8LvcYw\&cad=rja

55. Adhikari M. A total extinction confidently hoped for: The destruction of Cape San society under Dutch colonial rule, 1700-1795. J Genocide Res. 2010;12:19-44. https://doi.org/10.1080/14623528.2010.508274

56. Saugestad S. The inconvenient indigenous. Remote area development in Botswana, donor assistance and the first people of the Kalahari [PhD thesis]. Tromsø: University of Tromsø; 1999.

57. Rebelo AG, Holmes PM, Dorse C, Wood J. Impacts of urbanisation in a biodiversity hotspot: Conservation challenges in Metropolitan Cape Town. S Afr J Bot. 2011;77:20-35. https://doi.org/10.1016/j.sajb.2010.04.006

58. Berkes F, Folke C, Gadgil M. Traditional ecological knowledge, biodiversity, resilience and sustainability. Biodivers Conserv. 1995:281-299. https://doi. org/10.1007/978-94-011-0277-3_15

59. Secretariat of the Convention on Biological Biodiversity. Programme of work on protected areas (CBD programmes of work). Montreal: Secretariat of the Convention on Biological Diversity; 2004.

60. Wilshusen P, Brechin S, Fortwrangler C, West P. Reinventing a square wheel: Critique of a resurgent "protection paradigm" in international biodiversity conservation. Soc Nat Resour. 2002;15:17-40. https://doi. org/10.1080/089419202317174002

61. Cocks ML. Biocultural diversity: Moving beyond the realm of 'indigenous' and 'Iocal' people. Hum Ecol. 2006;34:185-200. https://doi.org/10.1007/ s10745-006-9013-5

62. Brockington D, Igoe J, Schmidt-Soltau K. Conservation, human rights and poverty reduction. Conserv Biol. 2006;20(1):250-252. https://doi. org/10.1111/j.1523-1739.2006.00335.x

63. Dold AP, Cocks ML. The medicinal use of some weeds, problem and alien plants in the Grahamstown and Peddie Districts of the Eastern Cape, South Africa. S Afr J Sci. 2000;96:467-475. 